Gulawentah: Jurnal Studi Sosial

ISSN 2528-6293 (Print); ISSN 2528-6871 (Online)

Vol. 4, No. 2, Desember 2019, Hal 78-84

Tersedia Online: http://e-journal.unipma.ac.id/index.php/gulawentah

\title{
Peran Perempuan Papua dalam Peningkatan Ekonomoni Keluarga di Kelurahan Wonosari Jaya Distrik Wania (Nilai Budaya dan Potensinya Sebagai Sumber Pembelajaran IPS SMP)
}

\author{
Eka Melianti dan Anjar Mukti Wibowo \\ Program Studi Pendidikan Sejarah, Universitas PGRI Madiun, Jl. Setiabudi No. 85 Madiun, \\ Indonesia \\ Email: ekameliantisejarah@yahoo.co.id; anjarmuktiwibowo@yahoo.com
}

\begin{abstract}
Abstrak
Penelitian ini bertujuan mengetahui untuk mendeskripsikan alasan perempuan Papua memenuhi kebutuhan ekonomi keluarganya, nilai-nilai budaya yang mendorong perempuan Papua bekerja dalam memenuhi kebutuhan ekonomi keluarganya, dan nilai budaya tersebut yang nantinya digunakan sebagai sumber pembelajaran IPS SMP. Dalam penelitian ini digunakan pendekatan kualitatif. Sumber data yang digunakan dalam penelitian ini yaitu sumber data primer dan sumber data sekunder. Teknik pengumpulan data menggunakan teknik wawancara, observasi langsung, dan dokumentasi. Sedangkan analisis data menggunakan teknik analisis secara interaktif dan berlangsung secara terus menerus. Dari hasil penelitian dapat disimpulkan bahwa (1) Perempuan Papua melakukan kewajiban menafkahi keluarganya merupakan sebuah kebiasaan yang sejak dahulu telah ada. Kebiasaan tersebut muncul dikarenakan sifat dari para laki-laki di masyarakat Papua; 2) Nilai yang mendorong adalah nilai kehidupan mengenai kasih sayang seorang ibu yang harus berjuang untuk keluarganya terutama anaknya; 3) Nilai budaya yang terdapat dalam kehidupan Perempuan Papua adalah nilai hubungan antar manusia dan alam serta manusia dan sesamanya, yang mana dapat dijadikan sebuah pembelajaran di SMP kelas VII semester ganjil dengan kompetensi dasar yaitu mengenai manusia sebagai makhluk sosial dan ekonomi yang bermoral dalam memenuhi kebutuhan.
\end{abstract}

Kata kunci: IPS; Nilai Budaya; Perempuan Papua

\section{The Role of Papuan Women in Increasing Family Economy in Wonosari Jaya Village, Wania District (Cultural Values and Their Potential as Social Resources for Junior High School Learning)}

\begin{abstract}
This study aims to describe the reasons for Papuan women to meet the economic needs of their families, cultural values that encourage Papuan women to work in meeting the economic needs of their families, and the cultural values that will be used as a source of junior high school social studies learning. In this study a qualitative approach was used. Data sources used in this study are primary data sources and secondary data sources. Data collection techniques using interview techniques, direct observation, and documentation. While the data analysis uses interactive analysis techniques and takes place continuously. From the results of the study it can be concluded that (1) Papuan women undertake the obligation to provide for their families is a habit that has always existed. This habit arises because of the nature of the men in Papuan society; 2)
\end{abstract}

DOI: 10.25273/gulawentah.v4i2.5523

Copyright (C) 2019 Universitas PGRI Madiun

All rights reserved. 
Encouraging value is the value of life regarding the love of a mother who must fight for her family, especially her children; 3) The cultural values inherent in the life of Papuan women are the value of the relationship between humans and nature and humans and others, which can be used as a learning in odd seventh grade junior high school with basic competencies namely regarding human beings as moral social and economic beings in meeting the needs.

Keywords: Social Sciences; Cultural Values; Papuan Women

\section{Pendahuluan}

Papua merupakan sebuah provinsi terluas yang dimiliki Indonesia yang terletak di bagian paling timur wilayah Indonesia. Papua memiliki batasan wilayah, sebelah utara berbatasan dengan Samudera Pasifik, sebelah selatan Samudera Hindia, sebelah barat Papua Barat, sebelah timur Papua Nugini. Pulau Papua berada di ujung timur dari wilayah Indonesia, dengan potensi sumber daya alam yang bernilai ekonomis dan strategis. Sehingga tidak heran Freeport sebagai perusahan tambang terbesar dunia beroperasi di wilayah ini, lebih tepatnya di daerah dataran tinggi Tembagapura, Kabupaten Mimika, Provinsi Papua. Luas wilayah dan memiliki potensi perekonomian yang bagus membuat wilayah Kabupaten Mimika dijadikan sebagai peruntungan untuk mengadu nasib dalam menaikkan perekonomian keluarga.

Berdasarkan berita resmi statistik perekonomian di Papua mengenai pertumbuhan ekonomi Papua triwulan II-2018 dibandingkan dengan triwulan II-2017. Perekonomiannya mengalami peningkatan 24,68 persen, pertumbuhan ekonominya didukung oleh semua lapangan usaha. Pertumbuhan tersebut sedikit melambat dari triwulan sebelumnya yang tumbuh sebesar 26,08 persen. Pertumbuhan tertinggi dicapai oleh lapangan usaha pertambangan dan penggalian sebesar 56,03 persen. Dari berita resmi diatas dapat dilihat bahwa kekuatan terbesar dalam menggerakkan perekonomian di Papua terdapat pada bidang pertambangan. Sektor pertambangan bisa dikatakan sebagai jantung perekonomian di Papua, ketika perekonomian disektor pertambangan mengalami penurunan maka hal tersebut juga akan berdampak langsung kepada masyarakat sekitarnya.

Manusia terdiri dari laki-laki dan perempuan, yang mana mereka memiliki perannya masingmasing dalam masyarakat dan lingkunganya. Setiap manusia memiliki status sosialnya masingmasing sesuai dengan hak dan kewajibannya. Status sosial merupakan kedudukan seseorang dalam masyarakat. Sedangkan peran sosial dapat dikatakan sebagai pelaksanaan hak dan kewajiban seseorang sesuai dengan status sosialnya. Perempuan yang bekerja di luar dari levelnya sebagai seorang perempuan atau istri dalam keluarga, membuat para perempuan tersebut menjadi lebih maju dan tangguh dalam hal bergerak maupun berfikir. Seperti para perempuan papua yang berada di Kelurahan Wonosari Jaya Kecamatan Mimika Baru Kabupaten Mimika, Papua. Faktor perekonomian yang mendorong mereka melakukan pekerjaan menjadi pedagang dipasar maupun berladang, hal itu untuk membantu perekonomian keluarga mereka. Walaupun di wilayah Kabupaten Mimika terdapat perusahaan besar dunia akan tetapi masih ada masyarakat papua khususnya kaum perempuan papua yang menjadi pekerja diluar tanggung jawab mereka sebagai seorang istri dan ibu.

Berbicara mengenai perempuan akan selalu berkaitan dengan hal-hal menarik. Perempuan sebagai makhluk Tuhan selalu mempunyai keunikan tersendiri. Keunikan tersebut akan terlihat ketika kita membahas mengenai kodratnya dan peran-perannya dalam rumah tangga. Terdapat anggapan bahwa perempuan merupakan makhluk Tuhan yang memiliki sifat lemah dan penuh kasih sayang karena perasaanya yang halus. Pada dasarnya perempuan memiliki sifat-sifat umum yaitu keindahan, kelembutan, serta rendah hati, dan memelihara (Marit, 2016). Dari sifat-sifat umum tersebutlah yang membuat perempuan memiliki sisi yang menarik untuk dibahas. Selain itu, Huda dan Wibowo (2017) mengatakan bahwa perempuan memiliki tiga peran dalam kehidupannya yaitu peran reproduktif, peran produktif dan peran sosial. Peran reproduktifnya diorientasikan terhadap kemampuan perempuan dalam mengurus rumah tangga atau suami, peran produktif 
menitikberatkan pada keterlibatan perempuan untuk menempatkan diri pada wilayah publik terutama mengenai pembagian kerja, sedangkan peran sosial lebih mengarah pada aktivitasnya di dalam kegiatan sosial masyarakat.

Pembahasan mengenai perempuan tidak akan terlepas dari masalah Gender. Topik mengenai gender selalu dibahas hampir disetiap sudut kehidupan. Gender sering dikaitkan dengan masalah pendidikan, politik, ekonomi dan juga pembahasan ringan ditengah-tengah lingkup masyarakat. Menurut Huda dan Wibowo (2017) berpendapat bahwa "hakikatnya konteks gender merupakan sebuah bentuk pembedaan berdasarkan jenis kelamin antara kelas laki-laki dan perempuan dalam sistem masyarakat". Menurut Marit (2016) menyebutkan konsep mendasar "gender identik dengan adanya pengertian sifat yang melekat pada kaum laki-laki dan perempuan baik secara sosial dan kultural". Dari beberapa pendapat diatas dapat dikatakan bahwa gender merupakan sebuah identitas personal seseorang sesuai dengan identitas dan peranannya dalam lingkup sosial masyarakat.

Menurut Yuliawati (2018) penggunaan kata perempuan daripada wanita kemungkinan disebabkan oleh pemahaman umum tentang makna dasar kata waita, yaitu wani ditata yang berarti mau diatur. Di sisi lain, makna kata perempuan dipandang meliputi semangat perjuangan karena berasal dari kata empu, yang bermakna ahli kerajinan. Dari pengertian itu, dapat dikatakan bahwa kata wanita digunakan untuk konteks pembahasan yang berkaitan dengan sifat lembut wanita dan sifat patuh wanita. Sendangkan kata perempuan digunakan pada ranah yang lebih keras atau berkaitan mengenai perjuangan. Dari berbagai sumber yang telah dijelaskan di atas, maka dalam perubahan peran perempuan dilihat berdasarkaan pada peran sosial seorang perempuan yang akan berubah menyesuaikan konteks permasalahan dalam lingkungannya, baik keluarga maupun masyarakat. Seorang perempuan akan mengalami perubahan peran pada saat menghadapi situasi seperti dibutuhkannya tenaga seorang perempuan dalam membantu keluarganya untuk memenuhi segala sesuatu terkait pemenuh kebutuhan keluarga.

Dalam kehidupan sehari-hari manusia akan selalu terlibat dengan bidang ekonomi. Ketika kita berbicara mengenai bidang ekonomi, akan selalu berkenaan mengenai pemenuh kebutuhan dan tentang transaksi jual beli. Dari situlah ekonomi dapat dikatakan sebagai suatu ilmu sosial yang berkaitkan dengan aktivitas manusia yang berhubungan dengan transaksi barang dan jasa. Hal ini berkaitan dengan pemenuh kebutuhan hidup. Kemudian yang dikatakan dengan ekonomi keluarga, merupakan sebuah ilmu sosial yang juga berkaitan dengan aktivitas perekonomian dalam pemenuhan kebutuhan rumah tangga (keluarga). Seiring berkembangnya zaman, peran perempuan juga bertambah. Dalam perkembangannya, seorang perempuan yang menyandang status sebagai seorang istri atau ibu terkadang mereka juga mendapat tugas seperti seorang ayah. Tugas seorang ayah lebih tempatnya berkaitan dengan mencari nafkah untuk kebutuhan keluarganya. Banyak faktor yang melatarbelakangi seorang perempuan yang sudah berkeluarga dan memiliki tugas yang cukup banyak dalam mengurus pekerjaan rumah tangga, masih menyisihkan waktu dan keringatnya untuk bekerja.

Pekerjaan yang mereka lakukan tersebut untuk pemenuhan kebutuhan pokok hidup mereka sendiri (Huda \& Wibowo, 2017). Pemenuhan kebutuhan pokok tersebut menyangkut kebutuhan rumah tangga. Peran perempuan dalam dimensi normatif dimaknai bahwa posisi perempuan sebagai ibu rumah tangga, pendamping suami dan pendidik anak. Hal tersebut menegaskan bahwa adanya perkembangan terhadap tugas perempuan saat ini, yang tidak hanya bertugas mengurus pekerjaan rumah tangga tetapi juga membantu perekonomian keluarga.

Setiap individu maupun masyarakat dalam kesehariannya akan selalu berhubungan dengan persoalan-persoalan yang bersifat ekonomi. Persoalan ekonomi tersebut bisa mencakup kegiatan seseorang ataupun masyarakat yang berkaitan dengan kegiatan ekonomi. Menurut Sukirno (2010) kegiatan ekonomi dapat didefinisikan sebagai suatu kegiatan seseorang atau suatu perusahaan ataupun suatu masyarakat untuk memproduksi barang dan jasa maupun mengkonsumsi (menggunakan) barang dan jasa tersebut. Berdasarkan hal tersebut maka kegiatan masyarakat ataupun individu dalam hal jual beli ataupun bertransaksi yang berkaitan dengan perdagangan merupakan kegiatan ekonomi. Kegiatan ekonomi juga didorong dengan adanya keharusan untuk memenuhi kebutuhan individu atau masyarakat dalam mencukupi kebutuhan ekonominya. 
Perilaku manusia dalam memenuhi kebutuhan hidupnya inilah merupakan sebuah kegiatan ekonomi. Menurut Sukirno (2010) pelaku-pelaku ekonomi dalam kegiatan ekonomi dibedakan menjadi tiga golongan, yaitu: rumah tangga, perusahaan, dan pemerintah. Rumah tangga (keluarga) adalah pemilik berbagai faktor produksi yang tersedia dalam perekonomian. Berbagai jenis pendapatan tersebut akan digunakan oleh rumah tangga (keluarga) untuk dua tujuan, yaitu untuk membeli berbagai barang ataupun jasa yang diperlukannya, selain itu juga untuk disimpan atau ditabung. Usaha yang dilakukan tersebut merupakan usaha oleh rumah tangga (keluarga) dalam pengelolaan ekonomi untuk pemenuhan kebutuhan keluarga. Hal tersebut juga dapat dikatakan sebagai upaya atau usaha dalam pengelolaan ekonomi keluarga.

Menurut Jayaputra (2012) Kabupaten Mimika ibu kotanya di Timika. Luasnya sekitar 21.522,77 Km2 atau 4,75\% dari luas wilayah Provinsi Papua dengan topografi dataran tinggi dan rendah. Distrik bertopografi di dataran tinggi yaitu Tembagapura, Agimuga dan Jila. Distrik di dataran rendah yang tidak berpantai atau berada di aliran sungai yaitu Mimika Baru dan Kuala Kencana. Sumber daya alam sangat bervariasi meliputi; flora dan fauna, pertambangan, dan wisata. Perhubungan antar daerah hanya udara dan laut. Jalur perhubungan udara di Kabupaten Mimika memiliki enam bandar udara salah satunya bandar udara Internasional Moses Kilangin di Timika. Berdasarkan data yang dijabarkan oleh Jayaputra tersebut Kabupaten Mimika memiliki potensi sumber daya alam yang sangat besar. Namun hingga saat ini untuk menuju ke wilayah Timika, hanya dapat ditempuh dengan jalur transportasi udara dan laut. Hal ini membuat perekonomian di daerah Timika berbeda dengan wilayah Papua pada umumnya. Biaya hidup di daerah Timika juga dapat dikatakan tinggi, karena transportasi atau biaya untuk menyupai bahan pangan hingga ke daerah ini memerlukan biaya yang cukup besar.

Nilai budaya menurut Uhin dalam (Hanif, 2016) merupakan konsepsi umum yang terorganisir dan dapat mempengaruhi perilaku manusia dalam hubungannya dengan lingkungan alam dan sosial, serta dengan sang maha pencipta. Nilai budaya tersebut menurut Hanif (2017) merupakan dikonstruksi ke dalam suatu sistem nilai budaya yang berupa pandangan hidup yang mempredisposisi tindakan dan perilaku manusia. Lebih dalam Koentjaraningrat (2009) mengatakan bahwa "nilai-nilai budaya dalam suatu kebudayaan berada dalam daerah emosional dari alam jiwa para individu yang menjadi warga sesuai dengan kebudayaan yang bersangkutan. Selain itu, para individu tersebut sejak kecil telah diresapi dengan nilai budaya yang ada dalam masyarakatnya sehingga konsep tersebut sejak lama telah berakar dalam alam jiwa mereka". Oleh sebab itu, suatu nilai budaya dalam masyarakat tidak dapat dengan mudah diubah dalam waktu singkat, karena sudah tertanam dan menjadi suatu kebiasaan bagi masyarakatnya. Nilai budaya yang ada juga merupakan suatu pedoman hidup bagi masyarakatnya.

Menurut (Koentjaraningrat, 2009) kelima masalah dasar dalam kehidupan manusia yang menjadi dasar bagi kerangka variasi sistem nilai budaya adalah (1) Masalah hakikat dari hidup manusia, (2) Masalah hakikat dari karya manusia, (3) Masalah hakikat dari kedudukan manusia dalam ruang waktu, (4) Masalah hakikat dari hubungan manusia dengan alam sekitarnya, (5) Masalah hakikat dari hubungan manusia dengan sesamanya. Dari berbagai masalah yang mendasari suatu nilai budaya yang terdapat dalam masyarakat tertentu dalam penelitian ini akan lebih dominan membahas mengenai masalah hakikat yang terdapat di masyarakat berhubungan dengan manusia dengan sesamanya.

Kehidupan manusia akan selalu memiliki adat-istiadat. Adat-istiadat tersebut terbentuk sesuai dengan norma atau kebiasaan dari masyarakat. Setiap adat-istiadat dari kelompok masyarakat pasti memiliki nilai yang didasari oleh beberapa hal yang masyarakat tersebut percayai. Menurut Koentjaraningrat (2009) sistem nilai budaya merupakan tingkat yang paling tinggi dan paling abstrak dari adat-istiadat. Hal itu disebabkan karena nilai budaya merupakan sebuah konsep mengenai sesuatu yang ada dalam alam pikiran sebagaian besar dari masyarakat yang mereka anggap bernilai, berharga, dan penting dalam hidup sehingga dapat berfungsi sebagai suatu pedoman yang memberi arah dan orientasi pada kehidupan para warga masyarakat tadi. Dari penjabaran tersebut dapat diketahui nilai budaya merupakan sebuah konsep dalam masyarakat yang

Gulawentah: Jurnal Studi Sosial Vol. 4, No. 2, Desember 2019, hal 78-84 
memiliki pemaknaan karena konsep tersebut memiliki arti atau nilai yang berharga. Berdasarkan berbagai sumber di atas maka nilai budaya yang akan difokuskan adalah nilai budaya yang berkaitan dengan hubungan manusia dengan sesamanya. Hal tersebut mengingat pembahasan pada penelitian ini mengenai peran perempuan dan kaitannya dengan ekonomi keluarga, yang mana semua aktivitas tersebut berkaitan dengan hubungan manusia dengan manusia. Selain itu, dalam tingkah laku manusia dalam masyarakat akan selalu berpedoman dengan tokoh-tokoh senior sebelum mereka.

Pengetahuan Sosial merupakan: (1) mata pelajaran bagi siswa sekolah dasar dan menengah, (2) mengenai kehidupan manusia dalam masyarakat, (3) bahannya bersumber pada berbagai disiplin ilmu sosial. Atau Pengetahuan Sosial merupakan perwujudan dari suatu pendekatan inter disiplin dari pelajaran ilmu-ilmu sosial dengna mengintegrasikan bahan/materi atau konsep-konsep ilmu sosial tersebut untuk memahami masalah-masalah sosial yang diberikan disekolah sebagai suatu program pengajaran. Dengan pemberian pelajaran ilmu pengetahuan sosial di sekolah, diharapkan siswa dapat belajar mengenai permasalahan-permasalahan dalam lingkungannya. Dalam pelajaran ilmu pengetahuan sosial siswa juga akan mengetahui seharusnya bagaimana mereka bertindak dalam situs dimasyarakat, dan mereka juga diharapkan dapat mengetahui penyelesaian dari masalah yang timbul dimasyarakat atau lingkungan sekitarnya.

Menurut buku yang diterbitkan oleh Departemen Pendidikan Nasional Guna mencapai tujuan pembelajaran dalam mata pelajaran IPS, guru hendaknya menyiapkan bahan pembelajran sebaik mungkin melalui langkah-langkah sebagai berikut: 1) mengenali sumber bahan pembelajaran, 2) memilih bahan pembelajaran yang sesuai, 3) menyusun bahan ajar tersebut agar menjadi isi bahan pembelajaran yang siap disajikan dalam proses pembelajaran. Materi pembelajaran IPS mencakup kajian yang luas yang berkaitan dengan kehidupan manusia. Sumber pembelajaran tersebut juga diharapakan dapat membantu guru dalam menyampaikan materi ajar yang mana diharapkan nantinya siswa akan lebih mudah memahami dalam proses belajar mengajar yang diberikan oleh guru.

\section{Metode Penelitian}

Penelitian ini menggunakan pendekatan kualitaif jenis penelitian dengan menggunakan metode deskriptif. Menurut Nazir (2011) metode deskriptif merupakan suatu metode dalam meneliti status sekelompok manusia, suatu obyek, suatu sistem pemikiran, ataupun suatu kelas peristiwa pada masa sekarang. Tujuan dari penelitian deskriptif ini adalah untuk membuat deskripsi, gambaran atau lukisan secara sistematis, faktual dan akurat mengenai fakta-fakta, sifatsifat serta hubungan antarfenomena yang diteliti. Penelitian ini dilaksanakan di Kelurahan Wonosari Jaya Distrik Wania Kabupaten Mimika. Adapun alasan peneliti memilih Kabupaten Mimika untuk dijadikan sebagai tempat penelitian yaitu, di Kabupaten Mimika ini belum pernah dilaksanakan penelitian dengan masalah yang sama. Selain itu, masih banyak generasi muda khususnya anak-anak putra maupun putri baik daerah ataupun pendatang yang belum mengetahui peran perempuan papua dalam bidang ekonomi keluarga dan nilai budaya yang terdapat di dalamnya. Waktu yang digunakan untuk melaksanakan penelitian ini yaitu bulan Maret sampai Juni 2019.

\section{Hasil dan Pembahasan}

Papua merupakan salah satu pulau yang paling besar di Indonesia. Wilayahnya begitu luas hingga sebagian besar wilayah di Papua masih berupa hutan. Selain itu, Papua juga terkenal dengan kehebatan para Perempuannya. Perempuan Papua hebat dalam berbagai hal seperti, mengayam noken, berkebut, berjualan dan juga mencari sagu di hutan. Pada penelitian ini peneliti lebih berfokus pada suku Papua yaitu Suku Amungme dan Suku Kamoro. Yang mana dalam hal ini suku tersebutlah yang bertempat tinggal di Kelurahan Wonosari Jaya Distrik Wania. Perempuan Papua disini banyak mengambil peran sosial dan ekonomi. Dalam hal ini menurut Marit (2016) perempuan memang mempunyai keunikan tersendiri, sejak membahas mengenai asal kejadiannya, kadar rasionalitasnya, kodratnya sampai kepada peran-perannya dalam rumah tangga. Adanya 
persepsi keunikan yang ada pada perempuan, hal tersebut muncul karena perempuan dipandang memiliki kodrat yang sama dengan laki-laki. Namun pada kenyataannya perempuan memiliki sifatnya sendiri dan tidak dapat disamakan dengan laki-laki. Oleh karenanya perempuan memiliki sifat yang lemah lembut, penyayang dan rendah hati.

Hal tersebut terbukti bahwasannya perempuan memiliki sifat lembut dan penyayang seperti halnya Perempuan Papua yang berada di Kelurahan Wonosari Jaya Distrik Wania. Perempuan Papua yang mayoritas sudah ibuk-ibuk atau mama tersebut memiliki aktivitas yang dominan dalam hal sosial ekonomi. Banyak ditemui Perempuan Papua yang melakukan aktivitas di hutan untuk mencari sayur-sayur untuk dijual di pasar. Selain itu, ada juga yang mencari sagu di hutan dan bercocok tanaman di ladang yang mana hal tersebut merupakan bentuk patuh mereka pada suami mereka. Namun banyak juga Perempuan Papua yang membawa bayi mereka untuk beraktivitas seperti berjualan di Pasar. Mereka membawa bayi mereka dengan menggunakan noken yang dikenakan di kepala mereka. Membawa bayi yang masih kecil untuk berjualan di Pasar yang hanya berada di pinggir jalan, hal tersebut akan memunculkan pemikiran bahwasannya tidak ada yang menjaga anak mereka ketika mereka beraktivitas mencari uang diluar rumah. Selain itu, tidak jarang kita akan sangat sulit menemui kaum laki-laki berada di pasar untuk berjualan.

Dari wawancara yang telah dilakukan oleh peneliti, beberapa informan yang berasal dari Suku Amungme mengatakan bahwa mereka berjualan dan melakukan kegiatan seperti bercocok tanaman untuk menghasilkan uang adalah sebuah bentuk rasa sayang pada keluarga dan membantu suami. Sedangkan untuk informan yang berasal dari Suku Kamoro mereka cenderung mengatakan bahwa mereka harus berusaha keras untuk mencari makan dan menyekolahkan anak karena suami mereka tidak bekerja.

Nilai merupakan hasil pertimbangan yang dibuat oleh seseorang atau masyarakat secara kelompok untuk menentukan penting atau berharganya suatu hal, gagasan atau praktek. Sedangkan untuk nilai budaya merupakan acuan bagi pemenuhan kebutuhan adab, yaitu kebutuhan-kebutuhan untuk mengetahui yang benar sebagai lawan yang salah, yang suci dari yang kotor, yang indah dari yang buruk, dan sebagainya (Prayogi \& Danial, 2016). Perempuan Papua yang memiliki aktivitas yang lebih dominan di dalam keluarganya maka hal tersebut juga di dorong oleh sebuah nilai yang berkembang dalam masyarakat yang cukup lama dan turun menurun diwariskan dari generasi ke generasi. Berdasarkan wawancara yang telah dilakukan oleh peneliti dari tanggal 13-20 Mei 2019. Peneliti melihat adanya nilai budaya yang berkaitan dengan hakikat hubungan manusia dengan alam sekitarnya serta hakikat manusia dengan sesamanya.

Hakikat hubungan manusia dengan alam sekitarnya seperti halnya Perempuan Papua yang berasal dari Suku Kamoro yang memiliki sebuah kebiasaan mengambil hasil alam di hutan kemudian dijual di pasar. Mereka mengambil hasil alam tersebut dengan cara hanya mengambil secukupnya. Mereka percaya bahwa alam sudah menyediakan apa saja yang mereka butuhan dalam kehidupan. Hanya saja kita sebagai manusia harus bisa baik juga ke alam agar alam tidak marah terhadap manusia. Selanjutnya, untuk nilai budaya yang berkaitan dengan hubungan manusia dengan sesamanya digambarkan oleh Perempuan Papua Suku Amungme. Perempuan Papua Suku Amungme menggambarkan bahwa perempuan itu bertugas sebagai asisten suami dalam rumah tangga. Asisten yang dimaksud adalah tugas seorang istri adalah untuk membantu suami agar kehidupan rumah tangga mereka terpenuhi. Kebiasaan dua Suku Papua yang berada di Kelurahan Wonosari Jaya Distrik Wania, yaitu Suku Amungme dan Suku Kamoro merupakan sebuah kebiasaan yang sudah ada sejak dahulu dan terus mengalir hingga sekarang. Sebuah kebiasaan tersebut mencari penciri dalam membedakan kelompok mereka.

Sumber Pembelajaran IPS merupakan suatu sarana pembelajaran yang digunakan oleh guru untuk mencapai tujuan pembelajaran. Guru hendaknya mempersiapkan bahan pembelajaran sebaik mungkin melalui langkah-langkah sebagai berikut: 1) mengenali sumber bahan pembelajaran, 2) memilih bahan pembelajaran yang sesuai, dan 3) menyusun bahan tersebut menjadi isi bahan pembelajaran yang siap digunakan dalam proses pembelajaran berlangsung. Dalam pembelajaran IPS, ruang lingkup pengetahuan sosial akan sangat luas. Hal tersebut mencakup: 1) Sistem sosial 
dan budaya 2) Manusia, tempat dan lingkungan 3) Perilaku ekonomi dan kesejahteraan 4) Waktu, keberlanjutan dan perubahan 5) Sistem berbangsa dan bernegara. Oleh karenanya dalam penelitian ini peneliti melihat adanya sebuah materi pembelajaran lokal yang belum dimasukkan dalam sistem atau kurikulum yang ada di sekolah dalam wilayah Kelurahan Wonosari Jaya Distrik Wania.

\section{Simpulan}

Perempuan merupakan makhluk Tuhan yang memiliki sifat yang lembut. Sifat lembut itu dapat terlihat baik dalam tutur kata, sikap ataupun rasa kasih dan sayangnya. Dalam keluarga seorang Ibu memiliki peran yang sangat penting. Ibu memiliki tanggung jawab yang sangat besar bagi keluarganya. Tanggung jawab tersebut seperti merapikan rumah, menyiapkan semua kebutuhan keluarga, dan juga mengawasi tumbuh kembang anaknya. Perempuan Papua yang berada di Kelurahan Wonosari Jaya Distrik Wania juga memiliki tugas yang besar. Perempuan Papua di wilayah ini memiliki tugas ganda dalam keluarga. Mereka sebagai seorang istri dan juga seorang ibu juga harus mengemban tugas sebagai seorang ayah, yaitu mencari nafkah untuk keluarga. Dalam Kelurahan Wonosari Jaya Distrik Wania masyarakat Papua yang mendiami wilayah ini berasal dari Suku Kamoro dan Suku Amungme. Dari setiap suku memiliki alasan berbeda karena kondisi atau situasi yang ada. Perempuan Suku Kamoro bekerja keras untuk keluarganya, karena tidak adanya sosok seorang suami atau bahkan ayah untuk anak-anaknya. Menurut mereka memang laki-laki dalam masyarakat mereka setelah berumah tangga yang hanya menganggur. Sehingga yang bekerja adalah kami para Perempuan. Hal berbeda terdapat pada Suku Amungme, yang mana mereka hidup berdampingan saling melengkapi dari tugas suami dan istri. Kebanyakan masyarakat Suku Amungme khususnya kaum perempuannya lebih menganggap mereka adalah seorang yang bertugas membantu suami dalam mengurusi keluarganya.

\section{Daftar Pustaka}

Hanif, M. (2016). Kesenian Dongkrek (Studi Nilai Budaya dan Potensinya Sebagai Sumber Pendidikan Karakter). Gulawentah: Jurnal Studi Sosial, 1(2), 132-141.

Hanif, M. (2017). Kesenian Ledug Kebuapten Magetan (Studi Nilai Simbolik dan Sumber Ketahanan Budaya). Gulawentah: Jurnal Studi Sosial, 2(2), 79-90.

Huda, K., \& Wibowo, A. M. (2017). Perempuan Kapuk. Yogyakarta: CV Budi Utama.

Jayaputra, A. (2012). Dinamika Masyarakat Mimika dalam Perspektif Ketahanan Sosial. Sosio Informa, 17(3).

Koentjaraningrat, K. (2009). Ilmu Antropologi. Jakarta: RIneka Cipta.

Marit, E. L. (2016). Noken Dan Perempuan Papua: Analisis Wacana Gender Dan Ideologi. Melanesia, 1(1), 33-42.

Nazir, M. (2011). Metode Penelitian. Bogor: Ghalia Indonesia.

Prayogi, R., \& Danial, E. (2016). Pergeseran Nilai-nilai Budaya pada Suku Bonai sebagai Civic Culture di Kecamatan Bonai Darussalam Kabupaten Rokan Hulu Provinsi Riau. HUMANIKA, 23(1), 61-79.

Sukirno, S. (2010). Mikro Ekonomi Teori Pengantar. Jakarta: Raja Grafindo Persada.

Yuliawati, S. (2018). Perempuan atau Wanita? Perbandingan Berbasis Korpus Tentang Leksikon Berbias Gender. Paradigma, Jurnal Kajian Budaya, 8(1), 53-70. 